\title{
Is ovarian cancer a targetable disease? A systematic review and meta-analysis and genomic data investigation
}

\author{
Nicoletta Staropoli ${ }^{1, *}$, Domenico Ciliberto ${ }^{1, *}$, Silvia Chiellino ${ }^{1}$, Francesca Caglioti ${ }^{1}$, \\ Teresa Del Giudice ${ }^{1}$, Simona Gualtieri ${ }^{1}$, Angela Salvino ${ }^{1}$, Alessandra Strangio ${ }^{1}$, \\ Cirino Botta ${ }^{1}$, Sandro Pignata ${ }^{2}$, Pierfrancesco Tassone ${ }^{1, *}$, Pierosandro Tagliaferri ${ }^{1, *}$ \\ ${ }^{1}$ Department of Experimental and Clinical Medicine, Magna Græcia University, Catanzaro, Italy \\ ${ }^{2}$ Department of Gynecologic and Urologic Oncology, Fondazione Pascale, National Cancer Institute of Naples, Naples, Italy \\ *These authors have contributed equally to this work \\ Correspondence to: Pierosandro Tagliaferri, email: tagliaferri@unicz.it \\ Keywords: ovarian cancer, targeted therapy, systemic chemotherapy, systematic review, meta-analysis \\ Received: May 01, $2016 \quad$ Accepted: September 25, $2016 \quad$ Published: October 13, 2016
}

\section{ABSTRACT}

Objectives: The current gold-standard for the first-line treatment in IIIb/IV stages of epithelial ovarian cancer (EOC) is the combination of carboplatin and paclitaxel plus bevacizumab in some countries. In the era of personalized medicine, there is still uncertainty on the impact of several molecularly targeted agents, which have been investigated for the management of this disease. To shed light on the actual role of targeted therapy in EOC, a systematic review and meta-analysis was performed.

Methods: Clinical trials were selected by searching "Pubmed" database and abstracts from major cancer meetings within the time-frame of January 2004-June 2015. The endpoints were survival outcome and response rate (RR). Hazard ratios (HRs) of survival outcomes, with confidence intervals and odds-ratios (ORs) of RR, were extracted from retrieved studies and used for current analysis. Meta-analysis was carried out by random effect model.

Results: 30 randomized trials for a total of 10,530 patients were selected and included in the final analysis. A benefit in terms of OS (pooled HR 0.915; $95 \% \mathrm{CI}$ $0.840-0.997 ; p=0.043$ ), particularly for anti-angiogenetic agents (HR $0.872 ; 95 \% C I$ 0.761-1.000; $p=0.049$ ), has been demonstrated for targeted therapy. Moreover, a significant advantage in platinum-resistant subgroup in term of PFS (HR $0.755 ; 95 \% \mathrm{CI}$ $0.624-0.912 ; p=0.004$ ) was found.

Conclusions: This systematic review and meta-analysis provide the first evidence that targeted therapy is potentially able to translate into improved survival of EOC patients, with a major role played by anti-angiogenetic drugs. The role of target therapy is underlined in the platinum-resistant setting that represents the "pain in the neck" in EOC management.

\section{BACKGROUND}

Description of epidemiology and clinical management

Epithelial ovarian cancer (EOC) is the leading cause of gynaecologic cancer mortality in developed countries. The overall 5 -years survival rate is $30 \%$, due to the absence of validated screening programs which often translates in advanced stage presentation [1]. Surgery is deemed to provide optimal tumour debulking, to assess pathology and to define the FIGO stage [2].

The role of chemotherapy both in adjuvant therapy and first line treatment is well established and carboplatin is still the mainstay of care worldwide [3]. The understanding of EOC biology in term of key events regulating most important signal transduction pathways and angiogenesis has led to the development 
of novel agents in EOC management [2, 4]. In the last years, 2 clinical trials successfully investigated the role of bevacizumab, an anti-VEGF monoclonal antibody, in the first-line treatment, showing significant advantage in term of progression free survival (PFS) in combination to standard carboplatin and paclitaxel schedule $[5,6]$. The selection of second-line treatment takes into account the efficacy of previous therapy, in term of the interval lenght from last platinum administration. On this basis, it is possible to offer platinum re-challenge to patients whose recurrence occurs 12 months after last platinum cycle and a different monotherapy in refractory/resistant platinum patients, whose recurrence occurs within 6 months from last platinum treatment [7-10].

\section{Hypothesis on disease pathobiology and new classification}

Regardless of the anatomical site, several findings indicate that the clinical outcome and prognosis of EOC are highly dependent on molecular and pathological features in which specific mutations (KRAS, PIK3CA, TP53, BRCA1 and BRCA2) are unequally distributed among different subtypes. Indeed, it is presently common thought that EOCs represent a "tree" of distinct pathological entities that share only the anatomic site [11]. On these bases, Shih and Kurman proposed a two-tier model of carcinogenesis, classifying EOC into 2 groups: Type I and Type II. The Type I that arises by precursor lesion and includes neoplasms that are commonly indolent, genetically stable and characterized by poor response to platinum-based chemotherapy; the Type II, characterized by de novo lesions, includes high-grade tumors that are usually diagnosed in advanced stages and are genetically unstable: frequently TP53 mutated, carry wild-type RAS genes and often germline or sporadic BRCA1/2 mutations or BRCA $1 / 2$ promoter methylation [12]. This last subgroup showed a strong correlation with response to platinum, probably due to early loss of BRCA $1 / 2$ and TP53 functions [13]. Moreover, about $50 \%$ of sporadic EOC display defects in the DNA repair homologous recombination (HR) pathway with subsequent inability to repair double-strand breaks induced by platinum compounds, as demonstrated in experimental in vitro and in vivo models [14-17]. Often, these patients report increased reliance on the poly (ADP-ribose) polymerase (PARP) single-strand repair pathway, although this evidence is recognized mostly in BRCA1/2 germline mutations carriers.

In a recent report from Cancer Genome Atlas (TCGA) Research Network 489 cases of high grade serous papillary EOC (HGS-OvCa) were analyzed by micro-arrays mRNA and miRNA profiling and genome sequencing [14]. This work provided the opportunity to identify 4 subtypes based on the expression of marker genes: "Differentiated", "Immunoreactive",
"Mesenchymal" and "Proliferative" with a potential prognostic and predictive role [18]. To validate this classification several retrospective sub-analyses on ICON7 trial demonstrated that it is possible to correlate a different outcome between the arms by gene expression and the use of biomarkers [6, 19-21].

\section{Role of inflammation, angiogenesis and molecular pathways involved}

Several studies investigated the role of inflammation, immune system and angiogenesis driving the idea that synthesis of cytokines, such as TNF- $\alpha$, IL$1 \beta$, IL-6, PGE-2 and vascular endothelial growth factor (VEGF) by cells from the microenvironment, promotes the onset and development of EOC [22]. A possible explanation of the central role of inflammation can be related to the inflammatory microenvironment that releases IL-6, whose levels are linked to poor prognosis, disease progression, residual disease after debulking surgery, ascites or anemia [23, 24]. Indeed IL-6 seems to play a key role in determining platinum-resistance inducing HIF-1 and STAT-3 expression/activity that promotes VEGF overexpression $[25,26]$. In turn VEGF supports ascites production, by increasing peritoneal permeability and immune suppression, by impairing dendritic cells maturation and Th1 response [27].

Although angiogenesis seems the major pathway involved in pathogenesis and progression of EOC, the epidermal growth factor receptor (EGFR)-family plays an important role in different malignancies and EGFR overexpression is correlated to decreased survival in EOC [28]. About 30-98\% of EOC present overexpression in one of these pathways. In particular, EGFR pathway seems to have a central role in cell proliferation, migration and invasion through the activation of several signalling pathways, such as RAS-RAF-mitogen-activated protein kinase pathway (RAS/RAF/MAPK pathway) that is able to determine a constitutive activation of STAT-3 and STAT-5 and the phosphatidylinositol 3-kinase pathway (PI3K) [29].

The aim of this work is to provide answer to the basic question if available literature actually supports the concept that molecular targeted agents indeed represent valuable tools for the treatment of EOC. In this light, we attempted to identify the relevance of single targetedpathway in molecularly unselected EOC patients and in several subgroups recognized by clinical criteria.

\section{RESULTS}

\section{Study selection and characteristics}

The PRISMA chart related to RCTs selection and search strategy is described in Figure 1. In the considered time-frame (2004-2015), 1558 studies were identified as 
full papers or meeting abstracts, while 1500 studies were initially excluded because reviews and/or for trial design. Thus, we examined in detail the remaining 58 trials. Among them, 28 trials were excluded because selection criteria were not met [30]. 30 trials for a total of 10530 patients were selected and included in the final analysis [5, 6, 10, 31-57].

In particular, 2 trials, both designed for multiple arms comparison, were analyzed for single comparison while 9 trials provided a primary treatment followed by a maintenance phase. At least one data-comparison in terms of survival outcome or RR was reported in all selected RCTs, which were therefore deemed eligible for the endpoint analysis. Summarizing the 30 trials included in final analyses: 19 were eligible for OS analysis (among them, we underlined, that: 10 were included in anti-angiogenetic analysis; 3 studies were included in anti-EGFR analysis; 3 studies were included in anti-PARP/DNA repair analysis; 3 trials were included in miscellaneous analysis); 27 were eligible for PFS analysis (among them, we underlined,

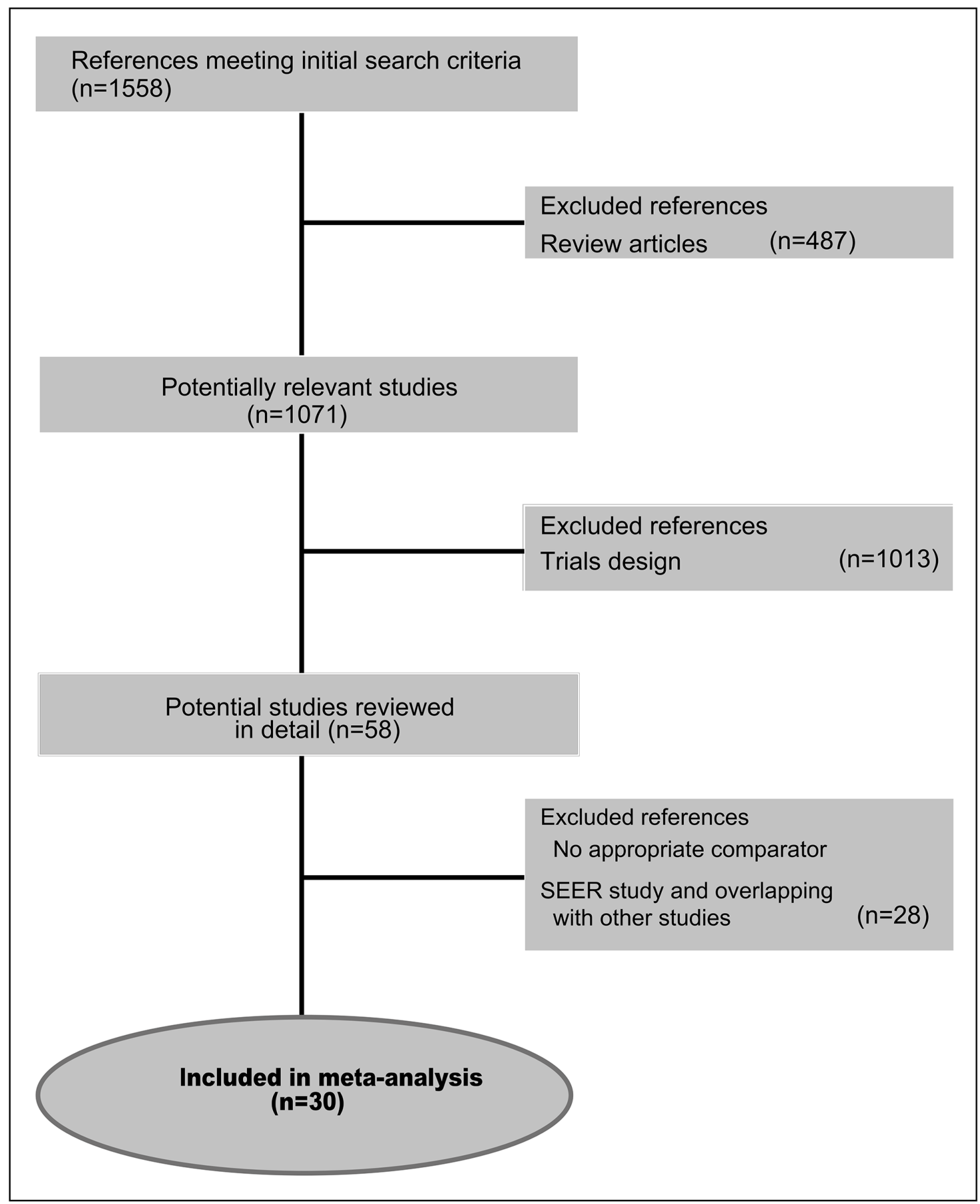

Figure 1: PRISMA chart showing the trial exclusion and inclusion process in the meta-analysis. 
that: 13 were included in anti-angiogenetic analysis; 4 studies were included in anti-EGFR analysis; 2 studies were included in anti-PARP/DNA repair; 8 trials were included in miscellaneous analysis), and 22 were evaluable for RR analysis (among them, we underlined, that: 10 were included in anti-angiogenic analysis; 3 studies were included in anti-EGFR analysis; 3 studies were included in anti-PARP/DNA repair; 6 trials were included in miscellaneous analysis).

\section{OS analyses}

Eleven trials were excluded from OS analysis because of missing data. Our OS analysis showed that targeted therapy plus conventional therapy produced a statistically significant, but marginal benefit in EOC patients compared to conventional therapy alone (pooled HR 0.915; 95\%CI 0.840-0.997; $p=0.043$; Figure 2). We reported a subgroup analysis on target-therapy pathway. In particular, a significant benefit for anti-angiogenetic agents only, in terms of OS (HR 0.872; 95\%CI 0.761$1.000 ; p=0.049$ ), was demonstrated (Supplementary data, Supplementary Figure S1). No statistically significant difference was found for other pathways. We performed a single meta-analysis considering 3 subgroups: platinumstatus, line of treatment and maintenance without evidence of significant differences in the subgroups for each analysis (Supplementary data, Supplementary Figures S2S4).

\section{PFS analyses}

Three trials were excluded from PFS analysis because of missing data. By our PFS analysis targeted therapy-based treatment demonstrated a significant benefit compared to a conventional treatment (pooled HR 0.807; 95\% CI 0.717-0.907; $p<0.001$; Figure 3). In more detail, we showed a significant benefit for anti-angiogenetic agents only, in terms of PFS (HR 0.740; 95\%CI 0.628$0.872 ; p<0.001)$. Moreover, we reported a significant advantage in subgroup analysis in relation to the line of treatment (HR 0.792 in second line versus 0.860 in first line; $p=0.004$ versus 0.006 , respectively) (Supplementary data, Supplementary Figures S5). In subgroup analysis for platinum-sensitivity, we reported an interesting and statistically significant benefit in platinum-resistant

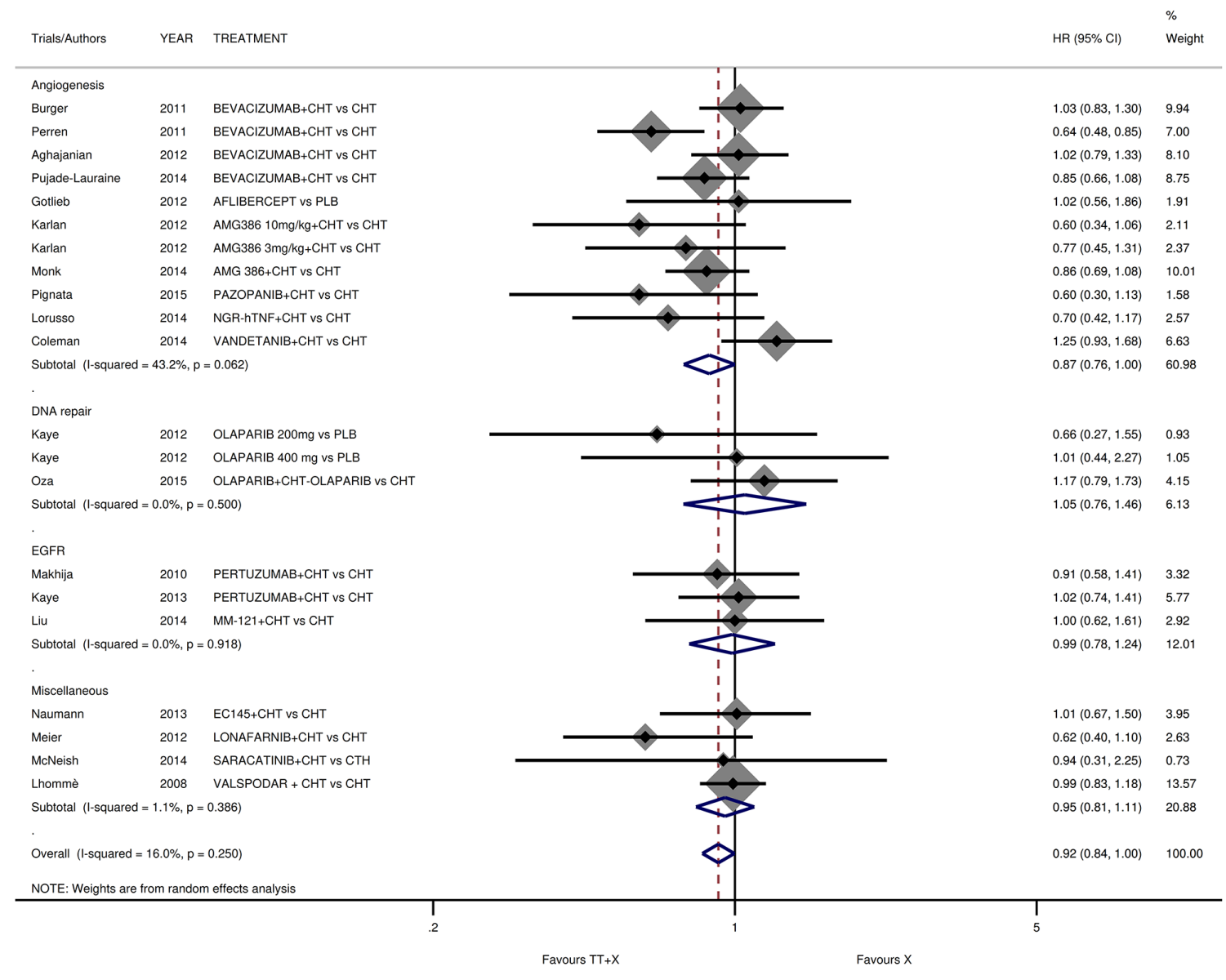

Figure 2: Comparison of OS according to involved pathway. Abbreviation: overall survival, OS; hazard ratio, HR; TT: target therapy; X: conventional therapy. 
patients only (HR $0.755 ; 95 \%$ CI $0.624-0.912 ; p=0.004$ ) (Supplementary data, Supplementary Figures S6). Finally, in subgroup with a maintenance (post-combination) phase, we reported a limited but statistically significant benefit in studies with or without maintenance (HR 0.709 in maintenance group versus 0.850 in no maintenance group; $p=0.002$ versus 0.021 , respectively) (Supplementary data, Supplementary Figures S7).

\section{RR analyses}

We excluded from this analysis 8 trials because missing data in terms of RR. No advantage was reported in RR analysis, (OR for RR 1.235; 95\%CI 0.970-1.571; $p=0.087$; Supplementary data, Supplementary Figure S8). In the anti-angiogenetic drugs analysis, we reported a significant improvement in term of RR (OR for RR $1.491 ; 95 \%$ CI 1.042-2.134; $p=0.029)$. No differences were reported in our subgroup analyses.

\section{Risk of bias in individual studies}

Begg's funnel plot and visual inspection showed a balanced evidence of publication bias $(\mathrm{p}=0.386$ ) (Figure 4).

\section{DISCUSSION}

This meta-analysis of $30 \mathrm{RCTs}$, containing 10,530 patients, compares regimens including targeted-agents versus systemic conventional treatments, stratified for each molecular pathway. While the aim of this work was the analysis of each pathway, we found a survival benefit for targeted-therapy in its whole (OS: pooled HR 0.91; PFS: pooled HR 0.80). Moreover, a benefit of targetedagents also in a subgroup analysis due to the effect of antiangiogenetic agents on survival endpoints was observed (HR 0.87; HR 0.74 for OS and PFS respectively). Importantly, a significant PFS gain in the platinumresistant patients was found (HR 0.75). To validate the findings here described, we performed sensitivity analyses on single involved pathway confirming pooled results previously reported.

Taking into account these findings, we may afford some possible explanations. First, our results underlined a significant advantage of anti-angiogenic therapy on all endpoints; RCTs investigating various anti-angiogenic agents in the treatment of EOC individually reported PFS benefit without OS advantage, aside from ICON6, for which a significant OS difference was reported [4, 58-60]. The efficacy of anti-angiogenetic therapy indicates that ovarian cancer is highly dependent on angiogenesis in advanced stage of disease.

Furthermore, we conducted an exploratory analysis comparing anti-angiogenetic TKIs (tyrosine-kinase inhibitors) and bevacizumab benefits, but we failed to demonstrate a difference in term of survival endpoints.
These findings indicate the occurrence of a class effect at meta-analytic evaluation and provide proof of concept for novel biomarker driven investigation. In our opinion the most interesting finding is the significant PFS benefit in platinum-resistant setting that underscored the importance of this class of drugs, in particular anti-angiogenic agents, in a subgroup with poor prognosis, considered resistant to conventional systemic treatment or surgery $[8,61]$. As mainly reported in the AURELIA trial, we show that the addition of anti-angiogenetic agents to standard chemotherapy produces significant benefits, particularly in combination with paclitaxel [10]. A possible explanation can rely on the thought that paclitaxel, administered in weekly schedule, has an anti-angiogenetic mechanism by itself $[62,63]$. However, the results from MITO11 trial, that investigated the combination of weekly paclitaxel with pazopanib, did not produce comparable findings [35]. It is possible to speculate that bevacizumab is able to produce in EOC a benefit which might reside not only in the anti-angiogenic activity but also in the immunomodulating and microenvironment-related effect [64]. It might be also hypothesized that bevacizumab could represent the optimal management for patients with a "mesenchymal disease", identified by the previously described new molecular classification. Conversely, it is possible that in "immune-reactive" disease new promising agents, such as anti-PD1 and anti-PDL1, could represent the optimal choice for the remarkable immune-system- and inflammation-dependency [65]. Unfortunately, we could not analyze this pathway because trials are still ongoing. Moreover, taking into account this new knowledge, an interesting research area relies on the possible role of microRNAs as therapeutic target $[66,67]$. Furthermore, the entity of benefit of targeted-agents is marginal in all reported subgroups examined, probably due to the absence of a priori selection of patients.

To date, several confirmatory trials, still ongoing, are designed at the aim of identifying potential predictive biomarkers in order to optimize the use of targeted-therapy [68].

In order to support our findings, we performed an exploratory analysis, using web-available datasets, at the aim to evaluate the expression of major potential biomarkers. In particular we accessed retrievable data from TCGA through CAN-EVOLVE portal (http://www. canevolve.org/AnalysisResults/AnalysisResults.html).

By Fisher test analysis, we recognized high expression of VEGFA in EOC. This analysis was validated with MannWhitney test in a free dataset (GSE14407) available in web, in which we confirmed that high expression of VEGFA, IL1b and CD31 genes were indeed associated with disease, underlining a potential role of inflammation and angiogenesis as driver pathways in EOC. In our opinion, these findings appear in line with the classeffect of anti-angiogenetic drugs. However, IL-6 and IL-8 did not show significant difference between normal and 
pathologic tissues in all datasets. Moreover, we observed a correlation between EOC and overexpression of ERBB2 that is generally reported in $<20 \%$ of EOC patients (Supplementary data, Supplementary Figures S9-S10). However, in our subgroup analysis on this pathway, we reported the absence of significant benefit. This finding could be explained taking into account that patients where not stratified on this biomarker. The role of maintenance is not established for the management of EOC. Indeed, several trials reported an improvement of PFS not confirmed in overall survival despite this approach. To date the major evidence for maintenance setting in EOC was limited to post-second-line treatment and for a particular subgroup of platinum sensitive patients with a recognized BRCA mutation that does not represent the aim of this manuscript.

Regarding the maintenance phase, in our analysis, we investigated only studies in which the targeted-therapy combined to chemotherapy was also offered in this phase.

Our results did not demonstrate a clear superiority of this approach on survival outcome, but lay the groundwork for the assessment of the studies that evaluate only targeted-therapy maintenance phase independently of previous treatment (e.g. olaparib, pazopanib, erlotinib). These studies, as specified in the methods of this work, were beyond the scope of this meta-analysis.

Regarding the response to targeted-drugs, it is known that RECIST criteria are not the most appropriate approach for measuring and monitoring target lesions in biological therapy. This consideration could justify the lack of significant benefit of targeted-therapy on RR endpoint.

Toxicity analyses are not shown in detail, but we found that diarrhea represents the only adverse event consistently reported in the experimental arms for all pathways, particularly for trials investigating TKIs. Hypertension and vascular events were observed with anti-angiogenetic agents, while skin toxicities were reported with anti-EGFR agents according to Literature data. It would be interesting to correlate toxicity with the possible efficacy of these drugs by the use of novel pharmacogenomics platforms, such as DMET [69]. This powerful approach is indeed suitable for biomarker identification for personalized EOC treatment.

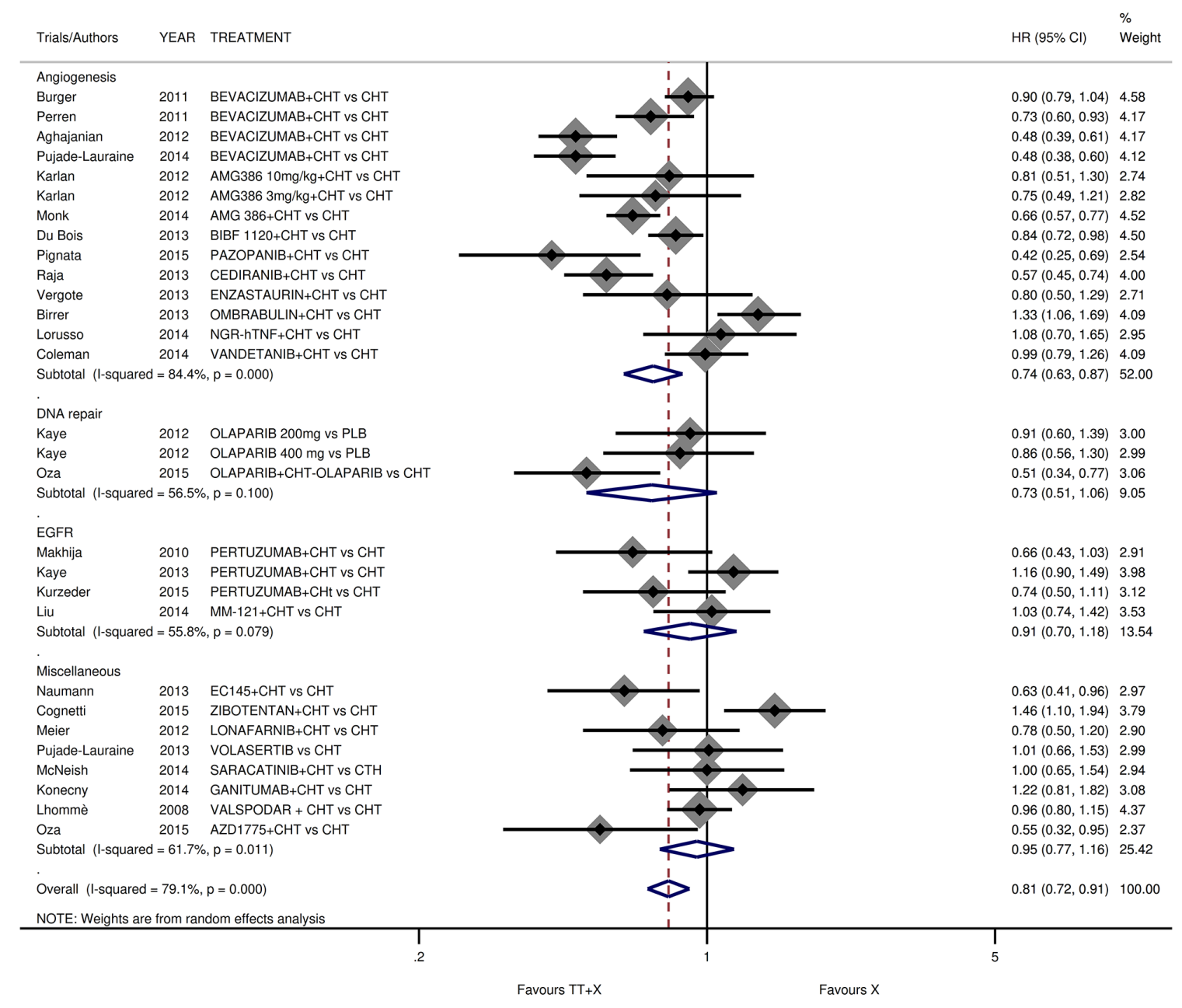

Figure 3: Comparison of PFS according to involved pathway. Abbreviation: progression free survival, PFS. 


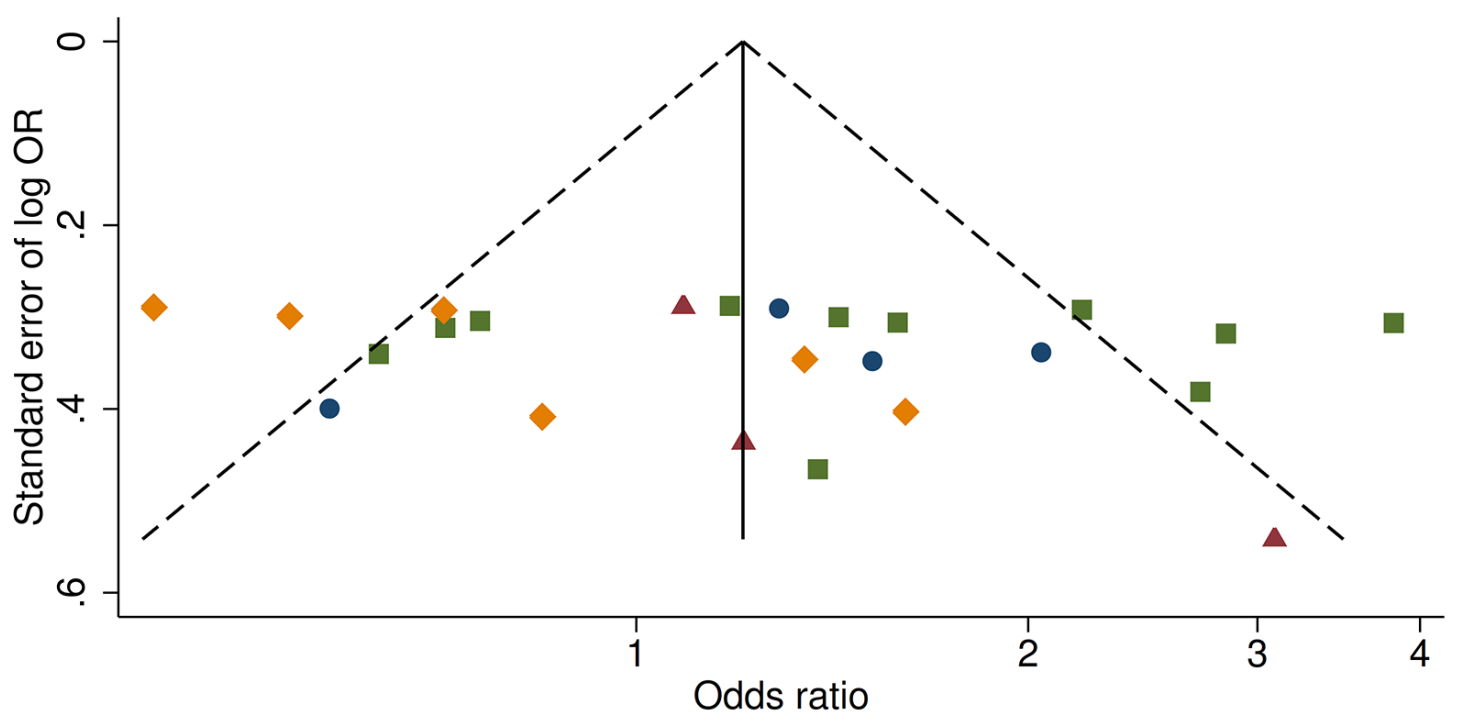

\begin{tabular}{|c|c|c|c|}
\hline - & DNA repair & $\Delta$ & EGFR \\
\hline - & Angiogenesis & $\diamond$ & Miscellaneous \\
\hline----- & Lower Cl & ----- & Upper CI \\
\hline 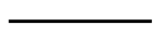 & Pooled & & \\
\hline
\end{tabular}

Figure 4: Funnel plot (Begg's test) assessing publication bias.

Nevertheless, an important limitation of this meta-analysis is that several investigated drugs did not represent a real option in the clinical practice, except for bevacizumab. Moreover, this work has been performed on Literature-derived data that do not allowed to retrieve all data related to all subgroups, and possibility to aggregate all the data of each single study for all selected endpoints.

Although PFS represent primary endpoint of several involved trials, this outcome could not represent at present an adequate surrogate endpoint for OS. Thus, our results in terms of overall survival must be interpreted in accordance with primary endpoint and not with an inferencial intent.

In the light of our results demonstrating OS benefit of targeted-therapy as a class-effect, it must be underlined that new clinical trials on pre-defined predictive biomarkers are eagerly awaited for a priori selection of patients in order to maximize the efficacy of these drugs and drastically reduce the costs of these treatments according to the health technology assessment. A possible new investigative approach could be provided by new trial design. Indeed this important "knowledge gap" represents a major limitation for development of a personalized therapeutic algorithm in the precision medicine era [70]. However, irrespective of the limitations of this work, we can conclude that both the good tolerability profile and the survival benefit indicate that targeted-therapy is potentially able to translate into improved survival of EOC patients, particularly in platinum-resistant setting that represent the "pain in the neck" of the EOC management.

\section{MATERIALS AND METHODS}

\section{Study design}

In order to evaluate the role of targeted therapybased schedules compared to conventional therapies in the management of EOC, we performed a systematic review and meta-analysis of all published prospective and RCTs designed on EOC in all treatment lines. Overall survival (OS), PFS and response rate $(\mathrm{RR})$ represent the predefined endpoints.

\section{Searching}

Bibliographic research was conducted by PubMed, Embase, and the Central Registry of Controlled Trials of the Cochrane Library, major meeting proceeding databases. The selected time frame referred was between January 2004 and June 2015 because, at our knowledge no modern targeted therapies were evaluated prior to that time. In order to reduce or minimize the risk of selection and information bias, only prospective and RCTs were evaluated in this analysis [71, 72]. The identified key-words are: "ovarian", "ovary", "tumor", "cancer", "advanced", "metastatic", "therapy", 
"targeted", "prospective", and "randomized" in different combinations: i.e. "epithelial ovarian cancer, targeted therapy". The 'related articles' function and references retrieved from articles were used to perform the search of all related studies, abstracts and citations.

\section{Selection}

In Table 1 are described all characteristics reported by patients enrolled in this work.

\section{Inclusion criteria}

Following are reported the inclusion criteria: Patients with diagnosis of EOC; Prospective and randomized clinical trials (RCTs), with or without blinding; abstracts or unpublished data if sufficient information on study design, characteristics of participants, interventions, and outcomes were available. We identified as experimental arm the targeted therapy-based schedule while the control arm was a conventional schedule for disease stage.

Table 1: Main characteristics of the randomised trials included in the meta-analysis

\begin{tabular}{|c|c|c|c|c|c|c|c|c|c|}
\hline $\begin{array}{l}\text { TRIALS } \\
\text { (first } \\
\text { author) }\end{array}$ & YEAR & TREATMENT & $\begin{array}{l}\text { TARGETED } \\
\text { PATHWAY }\end{array}$ & $\begin{array}{l}\text { Platinum } \\
\text { status }\end{array}$ & $\begin{array}{l}\text { PATI- } \\
\text { ENTS }\end{array}$ & $\begin{array}{c}\text { RR } \\
\text { control } \\
\text { arm }\end{array}$ & $\begin{array}{c}\text { RR } \\
\text { experimental } \\
\text { arm } \\
\end{array}$ & OS & PFS \\
\hline & & & & & & $(\%)$ & $(\%)$ & HR & HR \\
\hline Burger [9] & 2011 & $\begin{array}{c}\text { BEVACIZUMAB+CHT } \\
\text { vs CHT }\end{array}$ & angiogenesis & & 1873 & NR & NR & 1.03 & 0.9 \\
\hline Perren [10] & 2011 & $\begin{array}{c}\text { BEVACIZUMAB }+\mathrm{CHT} \\
\text { vs CHT }\end{array}$ & angiogenesis & & 1528 & 48 & 67 & 0.64 & 0.73 \\
\hline $\begin{array}{l}\text { Pujade- } \\
\text { Lauraine } \\
{[15]}\end{array}$ & 2014 & $\begin{array}{c}\text { BEVACIZUMAB+CHT } \\
\text { vs CHT }\end{array}$ & angiogenesis & resistant & 361 & 12 & 27 & 0.85 & 0.48 \\
\hline $\begin{array}{l}\text { Aghajanian } \\
\text { [50] }\end{array}$ & 2012 & $\begin{array}{c}\text { BEVACIZUMAB+CHT } \\
\text { vs CHT }\end{array}$ & angiogenesis & sensitive & 484 & 57 & 79 & 1.02 & 0.48 \\
\hline $\begin{array}{l}\text { Gotlieb } \\
\text { [51] }\end{array}$ & 2012 & $\begin{array}{c}\text { AFLIBERCEPT vs } \\
\text { PLB }\end{array}$ & angiogenesis & resistant & 55 & NR & NR & 1.02 & NR \\
\hline Karlan [52] & 2012 & $\begin{array}{l}\text { AMG386 10mg/ } \\
\mathrm{kg}+\mathrm{CHT} \text { vs CHT }\end{array}$ & angiogenesis & sens/resis & 108 & 27 & 37 & 0.6 & 0.81 \\
\hline Karlan [52] & 2012 & $\begin{array}{c}\mathrm{AMG} 3863 \mathrm{mg} / \\
\mathrm{kg}+\mathrm{CHT} \text { vs CHT }\end{array}$ & angiogenesis & sens/resis & 108 & 27 & 19 & 0.77 & 0.75 \\
\hline Monk [53] & 2014 & $\begin{array}{c}\text { AMG } 386+\text { CHT vs } \\
\text { CHT }\end{array}$ & angiogenesis & resistant & 919 & 30 & 38 & 0.86 & 0.66 \\
\hline $\begin{array}{l}\text { Pignata } \\
{[54]}\end{array}$ & 2015 & $\begin{array}{c}\text { PAZOPANIB+CHT vs } \\
\text { CHT }\end{array}$ & angiogenesis & resistant & 74 & 25 & 56 & 0.6 & 0.42 \\
\hline $\begin{array}{l}\text { Vergote } \\
{[55]}\end{array}$ & 2013 & $\begin{array}{c}\text { ENZASTAURIN+CHT } \\
\text { vs CHT }\end{array}$ & angiogenesis & & 142 & 39 & 43 & NR & 0.8 \\
\hline Raja [62] & 2013 & $\begin{array}{c}\text { CEDIRANIB }+ \text { CHT vs } \\
\text { CHT }\end{array}$ & angiogenesis & sensitive & 456 & NR & NR & NR & 0.57 \\
\hline Birrer [68] & 2013 & $\begin{array}{c}\text { OMBRABULIN+CHT } \\
\text { vs CHT }\end{array}$ & angiogenesis & sensitive & 154 & 71 & 65 & NR & 1.33 \\
\hline $\begin{array}{l}\text { Lorusso } \\
{[67]}\end{array}$ & 2014 & $\begin{array}{c}\text { NGR-hTNF+CHT vs } \\
\text { CHT }\end{array}$ & angiogenesis & resistant & 109 & NR & NR & 0.7 & 1.08 \\
\hline $\begin{array}{l}\text { Hainsworth } \\
\text { [70] }\end{array}$ & 2015 & $\begin{array}{c}\text { SORAFENIB+CHT vs } \\
\text { CHT }\end{array}$ & angiogenesis & & 85 & 74 & 67 & NR & NR \\
\hline $\begin{array}{l}\text { Coleman } \\
{[74]}\end{array}$ & 2014 & $\begin{array}{l}\text { VANDETANIB+CHT } \\
\text { vs CHT }\end{array}$ & angiogenesis & resistant & 131 & 9 & 12 & $\begin{array}{l}1.25 \\
\text { (Con }\end{array}$ & $\begin{array}{l}0.99 \\
\text { inued) }\end{array}$ \\
\hline
\end{tabular}




\begin{tabular}{|c|c|c|c|c|c|c|c|c|c|}
\hline $\begin{array}{l}\text { TRIALS } \\
\text { (first } \\
\text { author) }\end{array}$ & YEAR & TREATMENT & $\begin{array}{l}\text { TARGETED } \\
\text { PATHWAY }\end{array}$ & $\begin{array}{l}\text { Platinum } \\
\text { status }\end{array}$ & $\begin{array}{l}\text { PATI- } \\
\text { ENTS }\end{array}$ & $\begin{array}{c}\text { RR } \\
\text { control } \\
\text { arm }\end{array}$ & $\begin{array}{c}\text { RR } \\
\text { experimental } \\
\text { arm }\end{array}$ & OS & PFS \\
\hline & & & & & & $(\%)$ & $(\%)$ & HR & HR \\
\hline $\begin{array}{l}\text { Du Bois } \\
{[75]}\end{array}$ & 2013 & $\begin{array}{c}\text { BIBF } 1120+\mathrm{CHT} \text { vs } \\
\text { CHT }\end{array}$ & angiogenesis & & 1366 & NR & NR & NR & 0.84 \\
\hline Kaye [56] & 2012 & $\begin{array}{l}\text { OLAPARIB 200mg vs } \\
\text { PLB }\end{array}$ & DNA repair & sens/resis & 65 & 18 & 25 & 0.66 & 0.91 \\
\hline Kaye [56] & 2012 & $\begin{array}{c}\text { OLAPARIB } 400 \mathrm{mg} \text { vs } \\
\text { PLB }\end{array}$ & DNA repair & sens/resis & 65 & 18 & 31 & 1.01 & 0.86 \\
\hline Oza [63] & 2015 & $\begin{array}{l}\text { OLAPARIB+CHT- } \\
\text { OLAPARIB vs CHT }\end{array}$ & DNA repair & sensitive & 162 & 58 & 64 & 1.17 & 0.51 \\
\hline $\begin{array}{l}\text { Kummar } \\
{[64]}\end{array}$ & 2015 & $\begin{array}{c}\text { VELIPARIB+CHT vs } \\
\text { CHT }\end{array}$ & DNA repair & resistant & 74 & 19 & 12 & NR & NR \\
\hline $\begin{array}{l}\text { Makhija } \\
\text { [57] }\end{array}$ & 2010 & $\begin{array}{c}\text { PERTUZUMAB+CHT } \\
\text { vs CHT }\end{array}$ & EGFR & resistant & 130 & 5 & 14 & 0.91 & 0.66 \\
\hline Kaye [58] & 2013 & $\begin{array}{c}\text { PERTUZUMAB+CHT } \\
\text { vs CHT }\end{array}$ & EGFR & sensitive & 149 & 59 & 61 & 1.02 & 1.16 \\
\hline $\begin{array}{l}\text { Kurzeder } \\
{[65]}\end{array}$ & 2015 & $\begin{array}{c}\text { PERTUZUMAB }+\mathrm{CHt} \\
\text { vs CHT }\end{array}$ & EGFR & resistant & 154 & NR & NR & NR & 0.74 \\
\hline Liu [66] & 2014 & MM- $121+\mathrm{CHT}$ vs CHT & EGFR & resistant & 223 & 11 & 13 & 1 & 1.027 \\
\hline Meier [59] & 2012 & $\begin{array}{l}\text { LONAFARNIB+CHT } \\
\text { vs CHT }\end{array}$ & miscellaneous & & 105 & NR & NR & 0.62 & 0.78 \\
\hline $\begin{array}{l}\text { Naumann } \\
{[60]}\end{array}$ & 2013 & EC145+CHT vs CHT & miscellaneous & resistant & 149 & 12 & 18 & 1.01 & 0.63 \\
\hline $\begin{array}{l}\text { Cognetti } \\
{[61]}\end{array}$ & 2015 & $\begin{array}{l}\text { ZIBOTENTAN+CHT } \\
\text { vs CHT }\end{array}$ & miscellaneous & sensitive & 120 & 59 & 38 & NR & 1.46 \\
\hline $\begin{array}{l}\text { Pujade- } \\
\text { Lauraine } \\
{[69]}\end{array}$ & 2013 & VOLASERTIB vs CHT & miscellaneous & resistant & 109 & 15 & 13 & NR & 1.01 \\
\hline $\begin{array}{l}\text { Konecny } \\
{[71]}\end{array}$ & 2014 & $\begin{array}{l}\text { GANITUMAB+CHT } \\
\text { vs CHT }\end{array}$ & miscellaneous & & 170 & NR & NR & NR & 1.22 \\
\hline $\begin{array}{l}\text { Lhommè } \\
\text { [72] }\end{array}$ & 2008 & $\begin{array}{l}\text { VALSPODAR + CHT } \\
\text { vs CHT }\end{array}$ & miscellaneous & & 762 & 42 & 34 & 0.99 & 0.96 \\
\hline $\begin{array}{l}\text { McNeish } \\
{[73]}\end{array}$ & 2014 & $\begin{array}{c}\text { SARACATINIB+CHT } \\
\text { vs CTH }\end{array}$ & miscellaneous & resistant & 107 & 43 & 29 & 0.94 & 1 \\
\hline Oza [76] & 2015 & $\begin{array}{c}\text { AZD1775+CHT vs } \\
\text { CHT }\end{array}$ & miscellaneous & sensitive & 121 & 76 & 81 & & 0.55 \\
\hline
\end{tabular}

Abbreviations: overall survival, OS; progression free survival, PFS; hazard ratio, HR; TT: target therapy; ST: standard therapy; chemotherapy, CHT; best supportive care, BSC; not reported, NR.

\section{Exclusion criteria}

Non-comparative studies; non-prospective studies; non-comparable end-points; way of chemotherapy or targeted agents administration different from systemic, or oral (e.g. Intra-arterial or intra-peritoneal infusion). We excluded all trials focused only on maintenance phase of treatment.

\section{Data extraction}

In order to select homogeneous studies, 2 investigators (N.S. and D.C.) examined each trial, independently [73]. Any discrepancy was resolved by an arbiter (P.T.). From selected trials identified, the following variables were evaluated and efficacy results 
Table 2: Quality assessment

\begin{tabular}{|c|c|c|c|c|c|c|c|}
\hline $\begin{array}{l}\text { Included } \\
\text { studies }\end{array}$ & Year & $\begin{array}{c}\text { Method of } \\
\text { randomization }\end{array}$ & $\begin{array}{c}\text { Allocation } \\
\text { concealment }\end{array}$ & Blind & $\begin{array}{l}\text { Withdrawal } \\
\text { and dropout }\end{array}$ & Baseline & $\begin{array}{l}\text { Quality } \\
\text { level }^{\mathrm{a}}\end{array}$ \\
\hline Burger [9] & 2011 & centralized & central office & yes & $\begin{array}{l}\text { Detailed } \\
\text { criteria }\end{array}$ & identical baseline & A \\
\hline Perren [10] & 2011 & centralized & central office & no & $\begin{array}{l}\text { Detailed } \\
\text { criteria }\end{array}$ & identical baseline & A \\
\hline $\begin{array}{l}\text { Pujade- } \\
\text { Lauraine [15] }\end{array}$ & 2014 & No detailed & No detailed & no & $\begin{array}{l}\text { Detailed } \\
\text { criteria }\end{array}$ & identical baseline & B \\
\hline $\begin{array}{l}\text { Aghajanian } \\
{[50]}\end{array}$ & 2012 & centralized & central office & yes & $\begin{array}{l}\text { Detailed } \\
\text { criteria }\end{array}$ & identical baseline & A \\
\hline Gotlieb [51] & 2012 & centralized & central office & yes & $\begin{array}{l}\text { Detailed } \\
\text { criteria }\end{array}$ & identical baseline & A \\
\hline Karlan [52] & 2012 & centralized & central office & yes & $\begin{array}{l}\text { Detailed } \\
\text { criteria }\end{array}$ & identical baseline & A \\
\hline Monk [53] & 2014 & centralized & central office & yes & $\begin{array}{l}\text { Detailed } \\
\text { criteria }\end{array}$ & identical baseline & A \\
\hline Pignata [54] & 2015 & centralized & central office & no & $\begin{array}{l}\text { Detailed } \\
\text { criteria }\end{array}$ & identical baseline & A \\
\hline Vergote [55] & 2013 & centralized & central office & yes & $\begin{array}{l}\text { Detailed } \\
\text { criteria }\end{array}$ & identical baseline & A \\
\hline Kaye [56] & 2012 & centralized & central office & no & $\begin{array}{l}\text { Detailed } \\
\text { criteria }\end{array}$ & identical baseline & A \\
\hline Makhija [57] & 2010 & centralized & central office & yes & $\begin{array}{l}\text { Detailed } \\
\text { criteria }\end{array}$ & identical baseline & A \\
\hline Kaye [58] & 2013 & No detailed & no detailed & no & $\begin{array}{l}\text { Detailed } \\
\text { criteria }\end{array}$ & identical baseline & B \\
\hline Meier [59] & 2012 & centralized & central office & no & $\begin{array}{l}\text { Detailed } \\
\text { criteria }\end{array}$ & identical baseline & A \\
\hline Naumann [60] & 2013 & centralized & central office & no & $\begin{array}{l}\text { Detailed } \\
\text { criteria }\end{array}$ & identical baseline & A \\
\hline Cognetti [61] & 2013 & centralized & central office & yes & $\begin{array}{l}\text { Detailed } \\
\text { criteria }\end{array}$ & identical baseline & A \\
\hline Raja [62] & 2013 & centralized & central office & yes & $\begin{array}{l}\text { Detailed } \\
\text { criteria }\end{array}$ & identical baseline & A \\
\hline Oza [63] & 2015 & centralized & central office & no & $\begin{array}{l}\text { Detailed } \\
\text { criteria }\end{array}$ & identical baseline & A \\
\hline Kummar [64] & 2015 & No detailed & no detailed & no & no detailed & identical baseline & $\mathrm{C}$ \\
\hline Kurzeder [65] & 2015 & centralized & central office & yes & $\begin{array}{l}\text { Detailed } \\
\text { criteria }\end{array}$ & identical baseline & A \\
\hline Liu [66] & 2014 & No detailed & no detailed & no & $\begin{array}{l}\text { Detailed } \\
\text { criteria }\end{array}$ & identical baseline & B \\
\hline Lorusso [67] & 2014 & No detailed & no detailed & no & $\begin{array}{l}\text { Detailed } \\
\text { criteria }\end{array}$ & identical baseline & B \\
\hline
\end{tabular}

(Continued) 


\begin{tabular}{lccccccc}
\hline $\begin{array}{l}\text { Included } \\
\text { studies }\end{array}$ & Year & $\begin{array}{c}\text { Method of } \\
\text { randomization }\end{array}$ & $\begin{array}{c}\text { Allocation } \\
\text { concealment }\end{array}$ & Blind & $\begin{array}{c}\text { Withdrawal } \\
\text { and dropout }\end{array}$ & Baseline & $\begin{array}{c}\text { Quality } \\
\text { level }^{\text {a }}\end{array}$ \\
\hline Birrer [68] & 2013 & centralized & central office & yes & $\begin{array}{c}\text { Detailed } \\
\text { criteria }\end{array}$ & identical baseline & A \\
$\begin{array}{l}\text { Pujade- } \\
\text { Lauraine [69] }\end{array}$ & 2013 & No detailed & no detailed & no & $\begin{array}{c}\text { Detailed } \\
\text { criteria }\end{array}$ & identical baseline & B \\
$\begin{array}{l}\text { Hainsworth } \\
\text { [70] }\end{array}$ & 2015 & No detailed & no detailed & no & $\begin{array}{c}\text { Detailed } \\
\text { criteria }\end{array}$ & identical baseline & B \\
Konecny [71] & 2014 & centralized & central office & yes & $\begin{array}{c}\text { Detailed } \\
\text { criteria }\end{array}$ & identical baseline & A \\
Lhommè [72] & 2008 & No detailed & no detailed & no & $\begin{array}{c}\text { Detailed } \\
\text { criteria }\end{array}$ & identical baseline & B \\
McNeish [73] & 2014 & centralized & central office & no & $\begin{array}{c}\text { Detailed } \\
\text { criteria }\end{array}$ & identical baseline & A \\
Coleman [74] & 2014 & No detailed & no detailed & no & $\begin{array}{c}\text { Detailed } \\
\text { criteria }\end{array}$ & identical baseline & B \\
Du Bois [75] & 2013 & centralized & central office & yes & $\begin{array}{c}\text { Detailed } \\
\text { criteria }\end{array}$ & identical baseline & A \\
Oza [76] & 2015 & No detailed & no detailed & no & $\begin{array}{c}\text { Detailed } \\
\text { criteria }\end{array}$ & identical baseline & B \\
\hline
\end{tabular}

${ }^{a}$ See Methods for definition

were extracted: first author, number of patients enrolled, year of publication, treatment schedule, involved pathway, a maintenance phase after combination treatment with the same targeted-agent, and so on. Efficacy endpoints previous specified (OS, PFS, RR) were analyzed. Data extraction was conducted according to the PRISMA statement.

\section{Quality assessment}

The quality assessment of selected studies was performed according to the Cochrane reviewers' handbook for five requirements: method of randomization, allocation concealment, blindness, withdrawal/dropout, and adequacy of follow-up [74]. Twenty trials were scored A (low risk of bias), 9 trials was scored B (intermediate risk of bias), and 1 trial was scored C (high risk of bias) (Table 2).

\section{Quantitative data synthesis}

In order to evaluate the effects of the targetedbased treatments [chemotherapy $+/$ - biologicals] in EOC management, we carried out this meta-analysis on prespecified end-points [75]. We extracted survival data as hazard ratios (HRs) of OS, and PFS with relative confidence intervals $(95 \% \mathrm{CI})$. The interaction between survival and experimental treatment was obtained by each study from the HRs logarithm. Method for dichotomous data (odds ratio assessment; 95\% CI) was used for calculating the overall effect of combined treatments on RR. Cochrane's Q-test and I $\mathrm{I}^{2}$ statistics were used to assess heterogeneity between studies and the randomeffects model was used for the analysis taking into account the intent of comparing trials based on drugs with different mechanisms of action. Pooled data analysis was performed according to the DerSimonian and Laird test [76]. The presence of publication bias was investigated through Begg's test by visual inspection of funnel plots [77]. A two-tailed $p$ value equal or lower than 0.05 was considered statistically significant. All the statistical analyses were performed by using STATA SE v. 14.1 (STATA_Corporation, Texas, USA) [78].

\section{Genomic dataset analysis}

We examined available Web-datasets for each gene involved in the pathways reported in our meta-analysis in order to identify the possible correlations between targeted agents and pathway related gene-expression. In particular, we carried out 2 different analyses: regarding TCGA dataset (584 samples of EOC) accessed through CANEVOLVE portal (http://www.canevolve.org/ AnalysisResults/AnalysisResults.html), the analyses were conducted by Fisher test; concerningGSE14407 free web-dataset, including 24 samples (12 normal and 12 pathological tissues), the analyses were conducted by Mann-Whitney test to confirm association with disease. 
A two-tailed $p$ value equal or lower than 0.05 was considered statistically significant. All the statistical analyses were performed using Graphpad Prism v.6.

\section{Contributors}

Nicoletta Staropoli, Domenico Ciliberto, Alessandra Strangio and Simona Gualtieri performed the systematic review and the meta-analysis of pooled data, Francesca Caglioti, Silvia Chiellino and Teresa Del Giudice searched the WEB databases and Cirino Botta took care of bioinformatics. Pierosandro Tagliaferri and Pierfrancesco Tassone supervised the work and together to Nicoletta Staropoli and Domenico Ciliberto wrote the paper. Angela Salvino and Sandro Pignata provided expert opinion and participated to all steps of study completion.

\section{ACKNOWLEDGMENTS}

This work is supported by $\mathrm{PhD}$ program of Magna Graecia University: "molecular oncology and translational and innovative medical and surgical techniques".

\section{CONFLICTS OF INTEREST}

Sandro Pignata and Pierosandro Tagliaferri participated to board of Roche.

\section{REFERENCES}

1. Ferlay J, Soerjomataram I, Ervik M, Dikshit R, Eser S, Mathers C, Rebelo M, Parkin DM, Forman D, Bray F. (2013). GLOBOCAN 2012 v1.0, Cancer Incidence and Mortality Worldwide: IARC CancerBase. No. 11 [Internet]. Lyon, France: International Agency for Research on Cancer.

2. Jayson GC, Kohn EC, Kitchener HC, Ledermann Ja. Ovarian cancer. Lancet. 2014; 6736. doi: 10.1016/ S0140-6736(13)62146-7.

3. Pignata S, Cannella L, Leopardo D, Pisano C, Bruni GS, Facchini G. (2011). Chemotherapy in epithelial ovarian cancer.

4. Zhou M, Yu P, Qu X, Liu Y, Zhang J. Phase III trials of standard chemotherapy with or without bevacizumab for ovarian cancer: A meta-analysis. PLoS ONE. 2013; 8. doi: 10.1371/journal.pone.0081858.

5. Burger Ra, Brady MF, Bookman Ma, Fleming GF, Monk BJ, Huang H, Mannel RS, Homesley HD, Fowler J, Greer $\mathrm{BE}$, Boente M, Birrer MJ, Liang SX. Incorporation of bevacizumab in the primary treatment of ovarian cancer. The New England journal of medicine. 2011; 365: 2473-83. doi: 10.1056/NEJMoa1104390.

6. Perren TJ, Swart AM, Pfisterer J, Ledermann Ja, PujadeLauraine E, Kristensen G, Carey MS, Beale P, Cervantes A, Kurzeder C, du Bois A, Sehouli J, Kimmig R, et al. A phase 3 trial of bevacizumab in ovarian cancer. The New England journal of medicine. 2011; 365: 2484-96. doi: 10.1056/ NEJMoa1103799.
7. Ledermann JA, Kristeleit RS. (2010). Optimal treatment for relapsing ovarian cancer. Annals of Oncology.

8. Staropoli N, Ciliberto D, Botta C, Fiorillo L, Grimaldi A, Lama S, Caraglia M, Salvino A, Tassone P, Tagliaferri P. Pegylated liposomal doxorubicin in the management of ovarian cancer: a systematic review and metaanalysis of randomized trials. Cancer Biol Ther. 2014; 15: 707-20. doi: 10.4161/cbt.28557.

9. Parmar M, Ledermann JA, Colombo N, Du Bois A, Delaloye JF, Kristensen GB, Wheeler S, Swart AM, Qian W, Torri V. Paclitaxel plus platinum-based chemotherapy versus conventional platinum-based chemotherapy in women with relapsed ovarian cancer: the ICON4/AGOOVAR-2.2 trial. Lancet. 2003; 361: 2099-106.

10. Pujade-Lauraine E, Hilpert F, Weber B, Reuss A, Poveda A, Kristensen G, Sorio R, Vergote I, Witteveen P, Bamias A, Pereira D, Wimberger P, Oaknin A, et al. Bevacizumab combined with chemotherapy for platinum-resistant recurrent ovarian cancer: The AURELIA open-label randomized phase III trial. J Clin Oncol. 2014; 32: 1302-8. doi: 10.1200/JCO.2013.51.4489.

11. Kurman RJ, Shih I-M. Molecular pathogenesis and extraovarian origin of epithelial ovarian cancer--shifting the paradigm. Human pathology. 2011; 42: 918-31. doi: 10.1016/j.humpath.2011.03.003.

12. Baudi F, Quaresima B, Grandinetti C, Cuda G, Faniello C, Tassone P, Barbieri V, Bisegna R, Ricevuto E, Conforti S, Viel A, Marchetti P, Ficorella C, et al. Evidence of a founder mutation of BRCA1 in a highly homogeneous population from southern Italy with breast/ovarian cancer. Human Mutation. 2001; 18: 163-4. doi: 10.1002/humu.1167.

13. Kurman RJ, Shih I-M. The origin and pathogenesis of epithelial ovarian cancer: a proposed unifying theory. The American journal of surgical pathology. 2010; 34: 433-43. doi: 10.1097/PAS.0b013e3181cf3d79.

14. Bell D, Berchuck A, Birrer M, Chien J, Cramer DW, Dao F, Dhir R, DiSaia P, Gabra H, Glenn P, Godwin AK, Gross J, Hartmann L, et al. (2011). Integrated genomic analyses of ovarian carcinoma.

15. Tassone P, Tagliaferri P, Perricelli A, Blotta S, Quaresima B, Martelli ML, Goel A, Barbieri V, Costanzo F, Boland CR, Venuta S. BRCA I expression modulates chemosensitivity of BRCA I- defective HCC1937 human breast cancer cells. British Journal of Cancer. 2003; 88: 1285-91.

16. Tagliaferri P, Ventura M, Baudi F, Cucinotto I, Arbitrio M, Di Martino MT, Tassone P. BRCA1/2 genetic background-based therapeutic tailoring of human ovarian cancer: hope or reality? J Ovarian Res. 2009; 2: 14. doi: 10.1186/1757-2215-2-14.

17. Tassone P, Di Martino MT, Ventura M, Pietragalla A, Cucinotto I, Calimeri T, Bulotta A, Neri P, Caraglia M, Tagliaferri P. Loss of BRCA1 function increases the antitumor activity of cisplatin against human breast cancer xenografts in vivo. Cancer Biol Ther. 2009; 8: 648-53.

18. Tothill RW, Tinker AV, George J, Brown R, Fox SB, Lade S, Johnson DS, Trivett MK, Etemadmoghadam D, Locandro 
B, Traficante N, Fereday S, Hung JA, et al. Novel molecular subtypes of serous and endometrioid ovarian cancer linked to clinical outcome. Clinical Cancer Research. 2008; 14: 5198-208. doi: 10.1158/1078-0432.CCR-08-0196.

19. Gourley C, McCavigan A, Perren T, Paul J, Michie CO, Churchman M, Williams A, McCluggage WG, Parmar M, Kaplan RS, Hill LA, Halfpenny IA, O'Brien EJ, et al. Molecular subgroup of high-grade serous ovarian cancer (HGSOC) as a predictor of outcome following bevacizumab. ASCO Meeting Abstracts. 2014; 32: 5502.

20. Winterhoff BJN, Kommoss S, Oberg AL, Wang C, Riska SM, Konecny GE, Fan J-B, Shridhar V, Goode EL, Kommoss F, Du Bois A, Hilpert F, Chien J, et al. Bevacizumab and improvement of progression-free survival (PFS) for patients with the mesenchymal molecular subtype of ovarian cancer. ASCO Meeting Abstracts. 2014; 32: 5509.

21. Herzog TJ, Spetzler D, Xiao N, Burnett K, Maney T, Voss A, Reddy S, Burger R, Krivak T, Powell M, Friedlander M, McGuire W. Impact of molecular profiling on overall survival of patients with advanced ovarian cancer. Oncotarget. 2016; 7: 19840-19849. doi: 10.18632/oncotarget.7835.

22. Chebouti I, Blassl C, Wimberger P, Neubauer H, Fehm T, Kimmig R, Kasimir-Bauer S. Analysis of disseminated tumor cells before and after platinum based chemotherapy in primary ovarian cancer. Do stem cell like cells predict prognosis? Oncotarget. 2016; 7: 26454-26464. doi: 10.18632/oncotarget.8524.

23. Macciò A, Madeddu C. (2012). Inflammation and ovarian cancer.

24. Maccio A, Madeddu C, Massa D, Mudu MC, Lusso MR, Gramignano G, Serpe R, Melis GB, Mantovani G. Hemoglobin levels correlate with interleukin-6 levels in patients with advanced untreated epithelial ovarian cancer: role of inflammation in cancer-related anemia. Blood. 2005; 106: 362-7. doi: 2005-01-0160 [pii]ไr10.1182/blood-2005-01-0160.

25. Anglesio MS, George J, Kulbe H, Friedlander M, Rischin D, Lemech C, Power J, Coward J, Cowin PA, House CM, Chakravarty P, Gorringe KL, Campbell IG, et al. IL6-STAT3-HIF signaling and therapeutic response to the angiogenesis inhibitor sunitinib in ovarian clear cell cancer. Clinical Cancer Research. 2011; 17: 2538-48. doi: 10.1158/1078-0432.CCR-10-3314.

26. Cohen S, Bruchim I, Graiver D, Evron Z, Oron-Karni V, Pasmanik-Chor M, Eitan R, Bernheim J, Levavi H, Fishman A, Flescher E. (2012). Platinum-resistance in ovarian cancer cells is mediated by IL- 6 secretion via the increased expression of its target cIAP-2. Journal of Molecular Medicine, pp. 1-12.

27. Gavalas NG, Liontos $M$, Trachana SP, Bagratuni $T$, Arapinis C, Liacos C, Dimopoulos MA, Bamias A. (2013). Angiogenesis-related pathways in the pathogenesis of ovarian cancer.

28. Arteaga C. Targeting HER1/EGFR: a molecular approach to cancer therapy. Seminars in oncology. 2003; 30: 3-14. doi: 10.1016/S0093-7754(03)00185-4.
29. Olayioye MA, Neve RM, Lane HA, Hynes NE. The ErbB signaling network: receptor heterodimerization in development and cancer. The EMBO journal. 2000; 19: 3159-67. doi: 10.1093/emboj/19.13.3159.

30. Kaye S, Kaufman B, Lubinski J, Matulonis U, Gourley C, Karlan B, Taylor D, Wickens M, Carmichael J. Phase II study of the oral parp inhibitor olaparib (AZD2281) versus liposomal doxorubicin in ovarian cancer patients with brca1 and/or BRCA2 mutations. Annals of Oncology. 2010; 21 : viii304. doi: http://dx.doi.org/10.1093/annonc/mdq526.

31. Aghajanian C, Blank SV, Goff BA, Judson PL, Teneriello MG, Husain A, Sovak MA, Yi J, Nycum LR. OCEANS: A randomized, double-blind, placebo-controlled phase III trial of chemotherapy with or without bevacizumab in patients with platinum-sensitive recurrent epithelial ovarian, primary peritoneal, or fallopian tube cancer. Journal of Clinical Oncology. 2012; 30: 2039-45. doi: 10.1200/ JCO.2012.42.0505.

32. Gotlieb WH, Amant F, Advani S, Goswami C, Hirte H, Provencher D, Somani N, Yamada SD, Tamby J-F, Vergote I. Intravenous aflibercept for treatment of recurrent symptomatic malignant ascites in patients with advanced ovarian cancer: a phase 2, randomised, double-blind, placebo-controlled study. LANCET ONCOLOGY. 2012; 13: 154-62. doi: 10.1016/S1470-2045(11)70338-2.

33. Karlan BY, Oza AM, Richardson GE, Provencher DM, Hansen VL, Buck M, Chambers SK, Ghatage P, Pippitt $\mathrm{CH}$, Brown JV, Covens A, Nagarkar RV, Davy M, et al. Randomized, double-blind, placebo-controlled phase II study of AMG 386 combined with weekly paclitaxel in patients with recurrent ovarian cancer. Journal of clinical oncology. 2012; 30: 362-71. doi: 10.1200/JCO.2010.34.3178.

34. Monk BJ, Poveda A, Vergote I, Raspagliesi F, Fujiwara K, Bae DS, Oaknin A, Ray-Coquard I, Provencher DM, Karlan BY, Lhomme C, Richardson G, Rincon DG, et al. Antiangiopoietin therapy with trebananib for recurrent ovarian cancer (TRINOVA-1): a randomised, multicentre, doubleblind, placebo-controlled phase 3 trial. Lancet Oncol. 2014; 15: 799-808. doi: 10.1016/S1470-2045(14)70244-X.

35. Pignata S, Lorusso D, Scambia G, Sambataro D, Tamberi S, Cinieri S, Mosconi AM, Orditura M, Brandes AA, Arcangeli V, Panici PB, Pisano C, Cecere SC, et al. Pazopanib plus weekly paclitaxel versus weekly paclitaxel alone for platinum-resistant or platinum-refractory advanced ovarian cancer (MITO 11): a randomised, open-label, phase 2 trial. The Lancet Oncology. 2015; 16: 561-8. doi: 10.1016/ S1470-2045(15)70115-4.

36. Vergote IB, Chekerov R, Amant F, Harter P, Casado A, Emerich J, Bauknecht T, Mansouri K, Myrand SP, Nguyen TS, Shi P, Sehouli J. Randomized, phase II, placebocontrolled, double-blind study with and without enzastaurin in combination with paclitaxel and carboplatin as first-line treatment followed by maintenance treatment in advanced ovarian cancer. Journal of clinical oncology. 2013; 31 : 3127-32. doi: 10.1200/JCO.2012.44.9116. 
37. Kaye SB, Lubinski J, Matulonis U, Ang JE, Gourley C, Karlan BY, Amnon A, Bell-McGuinn KM, Chen L-M, Friedlander M, Safra T, Vergote I, Wickens M, et al. Phase II, Open-Label, Randomized, Multicenter Study Comparing the Efficacy and Safety of Olaparib, a Poly (ADP-Ribose) Polymerase Inhibitor, and Pegylated Liposomal Doxorubicin in Patients With BRCA1 or BRCA2 Mutations and Recurrent Ovarian Cancer. Journal of Clinical Oncology. 2012; 30: 372-9. doi: 10.1200/ JCO.2011.36.9215.

38. Makhija S, Amler LC, Glenn D, Ueland FR, Gold MA, Dizon DS, Paton V, Lin C-Y, Januario T, Ng K, Strauss A, Kelsey S, Sliwkowski MX, et al. Clinical Activity of Gemcitabine Plus Pertuzumab in Platinum-Resistant Ovarian Cancer, Fallopian Tube Cancer, or Primary Peritoneal Cancer. Journal of Clinical Oncology. 2010; 28: 1215-23. doi: 10.1200/JCO.2009.22.3354.

39. Kaye SB, Poole CJ, Dańska Bidzińska A, Gianni L, Del Conte G, Gorbunova V, Novikova E, Strauss A, Moczko M, McNally VA, Ross G, Vergote I. A randomized phase II study evaluating the combination of carboplatin-based chemotherapy with pertuzumab versus carboplatin-based therapy alone in patients with relapsed, platinum-sensitive ovarian cancer. Annals of Oncology. 2013; 24: 148-52. doi: 10.1093/annonc/mds282.

40. Meier W, Du Bois A, Rau J, Gropp-Meier M, Baumann K, Huober J, Wollschlaeger K, Kreienberg R, Canzler U, Schmalfeldt B, Wimberger P, Richter B, Schröder W, et al. Randomized phase II trial of carboplatin and paclitaxel with or without lonafarnib in first-line treatment of epithelial ovarian cancer stage IIB-IV. Gynecologic Oncology. 2012; 126: 236-40. doi: 10.1016/j.ygyno.2012.04.050.

41. Naumann RW, Coleman RL, Burger RA, Sausville EA, Kutarska E, Ghamande SA, Gabrail NY, DePasquale SE, Nowara E, Gilbert L, Gersh RH, Teneriello MG, Harb WA, et al. PRECEDENT: A randomized phase II trial comparing vintafolide (EC145) and pegylated liposomal doxorubicin (PLD) in combination versus PLD alone in patients with platinum-resistant ovarian cancer. Journal of Clinical Oncology. 2013; 31: 4400-6. doi: 10.1200/JCO.2013.49.7685.

42. Cognetti F, Bagnato A, Colombo N, Savarese A, Scambia G, Sehouli J, Wimberger P, Sorio R, Harter P, Mari E, McIntosh S, Nathan F, Pemberton K, et al. A Phase II, randomized, double-blind study of zibotentan (ZD4054) in combination with carboplatin/paclitaxel versus placebo in combination with carboplatin/paclitaxel in patients with advanced ovarian cancer sensitive to platinum-based chemotherapy (AGO-O. Gynecologic Oncology. 2015; 130: 31-7. doi: 10.1016/j.ygyno.2012.12.004.

43. Raja F, Perren T, Embleton A, Rustin G, Jayson G, Swart A, Vaughan M, Hirte H, Stark D, Ledermann J. RANDOMISED DOUBLE-BLIND PHASE III TRIAL OF CEDIRANIB (AZD 2171) IN RELAPSED PLATINUM SENSITIVE OVARIAN CANCER: RESULTS OF THE ICON6 TRIAL. INTERNATIONAL JOURNAL OF GYNECOLOGICAL CANCER. 2013; 23.
44. Oza AM, Cibula D, Benzaquen AO, Poole C, Mathijssen RHJ, Sonke GS, Colombo N, Špaček J, Vuylsteke P, Hirte H, Mahner S, Plante M, Schmalfeldt B, et al. Olaparib combined with chemotherapy for recurrent platinum-sensitive ovarian cancer: a randomised phase 2 trial. The Lancet Oncology. 2015; 16: 87-97. doi: 10.1016/S1470-2045(14)71135-0.

45. Kummar S, Oza AM, Fleming GF, Sullivan DM, Gandara DR, Naughton MJ, Villalona-Calero MA, Morgan RJ, Szabo PM, Youn A, Chen AP, Ji J, Allen DE, et al. Randomized Trial of Oral Cyclophosphamide and Veliparib in HighGrade Serous Ovarian, Primary Peritoneal, or Fallopian Tube Cancers, or BRCA-Mutant Ovarian Cancer. Clinical Cancer Research. 2015; 21: 1574-82. doi: 10.1158/10780432.CCR-14-2565.

46. Kurzeder C, Bover I, Marme F, Rau J, Pautier P, Colombo $\mathrm{N}$, Lorusso D, Ottevanger P, Bjurberg M, Marth C, Barretina-Ginesta P, Vergote I, Floquet A, et al. Efficacy and safety of chemotherapy (CT) $\{+/-\}$ pertuzumab (P) for platinum-resistant ovarian cancer (PROC): AGO-OVAR 2.20/ENGOT-ov14/PENELOPE double-blind placebocontrolled randomized phase III trial. ASCO Meeting Abstracts. 2015; 33: 5504.

47. Liu J, Ray-Coquard IL, Selle F, Poveda A, Cibula D, Hirte HW, Raspagliesi F, Gladieff L, Harter P, Schiavetto I, Tabah-Fisch IM, MacBeath G, Czibere AG, et al. A phase II randomized open-label study of MM-121, a fully human monoclonal antibody targeting ErbB3, in combination with weekly paclitaxel versus weekly paclitaxel in patients with platinum-resistant/refractory ovarian cancers. ASCO Meeting Abstracts. 2014; 32: 5519.

48. Lorusso D, Scambia G, Colombo N, Reed N, Pisano C, Lord R, Mangili G, Mosconi A, Raspagliesi F, Palazzo A, Ditto A, Salutari V, Conte C, et al. Randomized phase II trial of NGR-hTNF with an anthracycline in platinumrefractory or -resistant ovarian cancer (OC). ASCO Meeting Abstracts. 2014; 32: 5523.

49. Birrer MJ, Bondarenko I, Tjulandin S, Vergote I, Cibula D, Ray-Coquard I, Colombo N, Allard A, Oprea C, Rey AA, Sessa C, Pujade-Lauraine E. Opsalin: A phase II placebo (Pbo)-controlled randomized study of ombrabulin in patients with platinum-sensitive recurrent ovarian cancer (OC) treated with carboplatin $(\mathrm{Cb})$ and paclitaxel $(\mathrm{P})$. ASCO Meeting Abstracts. 2013; 31: 5516.

50. Pujade-Lauraine E, Weber BE, Ray-Coquard I, Vergote I, Selle F, Del Campo JM, Sufliarsky J, Tschope I, Garin Chesa P, Nazabadioko S, Pilz K, Joly F. Phase II trial of volasertib (BI 6727) versus chemotherapy (CT) in platinumresistant/refractory ovarian cancer (OC). ASCO Meeting Abstracts. 2013; 31: 5504.

51. Hainsworth JD, Thompson DS, Bismayer JA, Gian VG, Merritt WM, Whorf RC, Finney LH, Dudley BS. Paclitaxel/ carboplatin with or without sorafenib in the first-line treatment of patients with stage III/IV epithelial ovarian cancer: a randomized phase II study of the Sarah Cannon Research Institute. Cancer Medicine. 2015; 4: 673-81. doi: 10.1002/cam4.376. 
52. Konecny GE, Haluska P, Janicke F, Sehouli J, Beckmann MW, Feisel G, Polcher M, Roman L, Rody A, Karlan B, Ray-Coquard IL, Provencher DM, Ben-Baruch N, et al. A phase II, multicenter, randomized, double-blind, placebocontrolled trial of ganitumab or placebo in combination with carboplatin/paclitaxel as front-line therapy for optimally debulked primary ovarian cancer: The TRIO14 trial. ASCO Meeting Abstracts. 2014; 32: 5529.

53. Lhommé C, Joly F, Walker JL, Lissoni AA, Nicoletto MO, Manikhas GM, Baekelandt MMO, Gordon AN, Fracasso PM, Mietlowski WL, Jones GJ, Dugan MH. Phase III Study of Valspodar (PSC 833) Combined With Paclitaxel and Carboplatin Compared With Paclitaxel and Carboplatin Alone in Patients With Stage IV or Suboptimally Debulked Stage III Epithelial Ovarian Cancer or Primary Peritoneal Cancer. Journal of Clinical Oncology. 2008; 26: 2674-82. doi: 10.1200/JCO.2007.14.9807.

54. McNeish IA, Ledermann JA, Webber L, James L, Kaye SB, Hall M, Hall G, Clamp A, Earl H, Banerjee S, Kristeleit R, Raja F, Feeney A, et al. A randomised, placebo-controlled trial of weekly paclitaxel and saracatinib (AZD0530) in platinum-resistant ovarian, fallopian tube or primary peritoneal cancer. Annals of Oncology. 2014; 25: 1988-95. doi: 10.1093/annonc/mdu363.

55. Coleman RL, Moon J, Sood AK, Hu W, Delmore JE, Bonebrake AJ, Anderson GL, Chambers SK, Markman M. Randomised phase II study of docetaxel plus vandetanib versus docetaxel followed by vandetanib in patients with persistent or recurrent epithelial ovarian, fallopian tube or primary peritoneal carcinoma: SWOG S0904. European Journal of Cancer. 2014; 50: 1638-48. doi: http://dx.doi. org/10.1016/j.ejca.2014.03.005.

56. Du Bois A KG. (2013). AGO-OVAR 12: a randomized placebo-controlled GCIG/ENGOT-Intergroup phase III trial of standard frontline chemotherapy/-nintedanib for advanced ovarian cancer. Int $\mathrm{J}$ Gynecol Cancer 2013;23(suppl 1):LBA, pp. 23.

57. Oza AM, Weberpals JI, Provencher DM, Grischke E-M, Hall M, Uyar D, Estevez-Diz MDP, Marme F, Kuzmin A, Rosenberg P, Wenham RM, Qiu J, Lee MA, et al. An international, biomarker-directed, randomized, phase II trial of AZD1775 plus paclitaxel and carboplatin $(\mathrm{P} / \mathrm{C})$ for the treatment of women with platinum-sensitive, TP53-mutant ovarian cancer. ASCO Meeting Abstracts. 2015; 33: 5506.

58. Li J, Li S, Chen R, Yu H, Lu X. The prognostic significance of anti-angiogenesis therapy in ovarian cancer: a metaanalysis. Journal of Ovarian Research. 2015; 8: 54. doi: 10.1186/s13048-015-0181-z.

59. Li J, Zhou L, Chen X, Ba Y. Addition of bevacizumab to chemotherapy in patients with ovarian cancer: a systematic review and meta-analysis of randomized trials. Clinical and Translational Oncology. 2015; 17: 673-83. doi: 10.1007/ s12094-015-1293-z.

60. Marchetti C, De Felice F, Palaia I, Musella A, Di Donato V, Gasparri ML, Musio D, Muzii L, Tombolini V, Panici PB.
Efficacy and toxicity of bevacizumab in recurrent ovarian disease: an update meta-analysis on phase III trials. Oncotarget. 2016; 7: 13221-13227. doi: 10.18632/oncotarget.6507.

61. Staropoli N, Botta C, Ciliberto D, Fiorillo L, De Angelis AM, Viscomi C, Gualtieri S, Salvino A, Tassone P, Tagliaferri P. Target Therapy in Platinum-Refractory/ Resistant Ovarian Cancer: From Preclinical Findings to Current Clinical Practice. 2013.

62. Pujade-Lauraine E, Hilpert F, Weber B, Reuss A, Poveda A, Kristensen G, Sorio R, Vergote I, Witteveen P, Bamias A, Pereira D, Wimberger P, Oaknin A, et al. AURELIA: A randomized phase III trial evaluating bevacizumab (BEV) plus chemotherapy (CT) for platinum (PT)resistant recurrent ovarian cancer (OC). Journal of Clinical Oncology. 2012; 30: LBA5002.

63. Trillsch F, Mahner S, Hilpert F, Davies LC, GarciaMartinez E, Kristensen G, Savarese A, Vuylsteke P, Los M, Zagouri F, Gladieff L, Sehouli J, Lee C, et al. Prognostic and predictive value of primary vs secondary platinum resistance for bevacizumab treatment in platinum-resistant ovarian cancer in the AURELIA trial. ASCO Meeting Abstracts. 2015; 33: 5552.

64. Garber K. Promising Early Results for ImmunotherapyAntiangiogenesis Combination. Journal of the National Cancer Institute. 2014; 106. doi: 10.1093/jnci/dju392.

65. Strickland KC, Howitt BE, Shukla SA, Rodig S, Ritterhouse LL, Liu JF, Garber JE, Chowdhury D, Wu CJ, D'Andrea AD, Matulonis UA, Konstantinopoulos PA. Association and prognostic significance of BRCA1/2-mutation status with neoantigen load, number of tumor-infiltrating lymphocytes and expression of PD-1/PD-L1 in high grade serous ovarian cancer. Oncotarget. 2016; 7: 13587-13598. doi: 10.18632/ oncotarget.7277.

66. Liu G, Yang D, Rupaimoole R, Pecot CV, Sun Y, Mangala LS, Li X, Ji P, Cogdell D, Hu L, Wang Y, RodriguezAguayo C, Lopez-Berestein G, et al. Augmentation of Response to Chemotherapy by microRNA-506 Through Regulation of RAD51 in Serous Ovarian Cancers. Journal of the National Cancer Institute. 2015; 107. doi: 10.1093/ jnci/djv108.

67. Meng X, Muller V, Milde-Langosch K, Trillsch F, Pantel K, Schwarzenbach H. Diagnostic and prognostic relevance of circulating exosomal miR-373, miR-200a, miR-200b and miR$200 \mathrm{c}$ in patients with epithelial ovarian cancer. Oncotarget. 2016; 7: 16923-16935. doi: 10.18632/oncotarget.7850.

68. Daniele G, Lorusso D, Scambia G, Di Napoli M, Nicoletto MO, Breda E, Colombo N, Artioli G, Daniele B, Lo Re G, Raspagliesi F, Chiappa V, Salutari V, et al. Feasibility and outcome of interval debulking surgery (IDS) after carboplatin-paclitaxel-bevacizumab (CPB): Results from a subgroup of patient from the MITO-16AMANGO OV2A phase 4 trial. ASCO Meeting Abstracts. 2015; 33: 5569.

69. Guzzi P, Agapito G, Di Martino M, Arbitrio M, Tassone P, Tagliaferri P, Cannataro M. DMET-Analyzer: automatic 
analysis of Affymetrix DMET Data. BMC Bioinformatics. 2012; 13: 258. doi: 10.1186/1471-2105-13-258.

70. Zhang D, Chen $\mathrm{P}$, Zheng $\mathrm{CH}$, Xia J. Identification of ovarian cancer subtype-specific network modules and candidate drivers through an integrative genomics approach. Oncotarget. 2016; 7: 4298-309. doi: 10.18632/ oncotarget.6774.

71. Parmar MKB, Torri V, Stewart L. (1998). Extracting summary statistics to perform meta-analyses of the published literature for survival endpoints. Statistics in Medicine, pp. 2815-34.

72. Stewart LA, Parmar MK, Tierney JF. (1998). Meta-analyses and large randomized, controlled trials.

73. LA S, Clarke M, Rovers M, al e. Preferred reporting items for a systematic review and meta-analysis of individual participant data: The prisma-ipd statement. JAMA. 2015; 313: 1657-65.
74. Detsky AS, Naylor CD, O'Rourke K, McGeer AJ, L'Abbé KA. Incorporating variations in the quality of individual randomized trials into meta-analysis. Journal of clinical epidemiology. 1992; 45: 255-65. doi: 10.1016/0895-4356(92)90085-2.

75. Crowther M, Lim W, Crowther MA. (2010). Systematic review and meta-analysis methodology.

76. DerSimonian R, RJ L. REsolving discrepancies between a meta-analysis and a subsequent large controlled trial. JAMA. 1999; 282: 664-70.

77. Sterne JAC, Becker BJ, Egger M. (2006). The Funnel Plot. Publication Bias in Meta-Analysis: Prevention, Assessment and Adjustments, pp. 73-98.

78. Gutierrez RG. Stata. Wiley Interdisciplinary Reviews: Computational Statistics. 2010; 2: 728-33. doi: 10.1002/ wics.116. 